Historic, Archive Document

Do not assume content reflects current scientific knowledge, policies, or practices. 



\section{Gharacteristics and Distribution of Itchgrass in Louisiana}

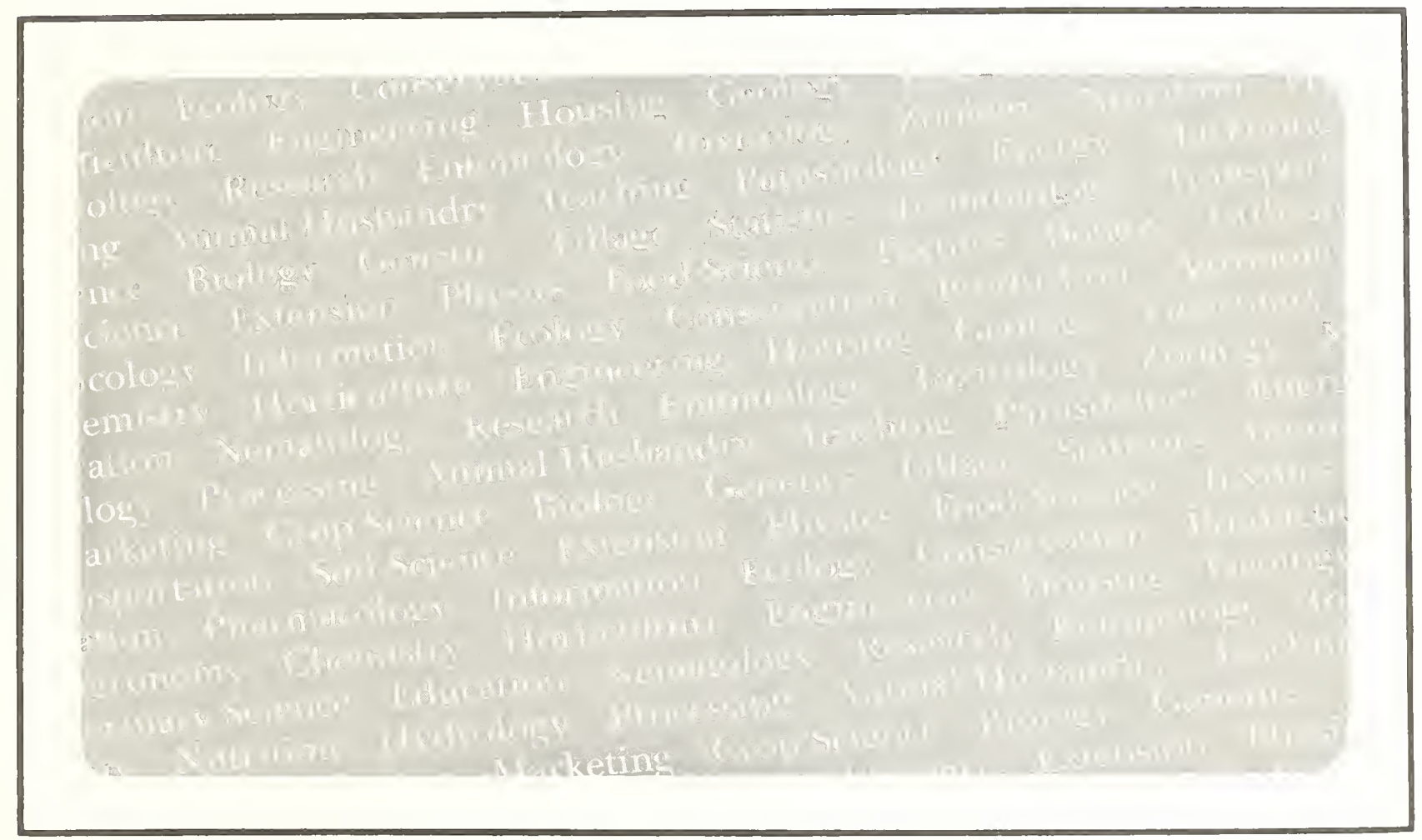

U.S. Department of Agriculture Science and Education Administration Agricultural Reviews and Manuals • ARM-S-7/November 1979 
The research reported in this publication was done in cooperation with the Mississippi Agricultural and Forestry Experiment Station and Louisiana Tech University.

This publication is available from the Southern Weed Science Laboratory, P.O. Box 225, Stoneville, Miss. 38776.

Science and Education Administration, Agricultural Reviews and Manuals, Southern Series, No. 7, November 1979.

Published by Agricultural Research (Southern Region), Science and Education Administration, U.S. Department of Agriculture, P.O. Box 53326, New Orleans, La. 70153. 


\section{CONTENTS}

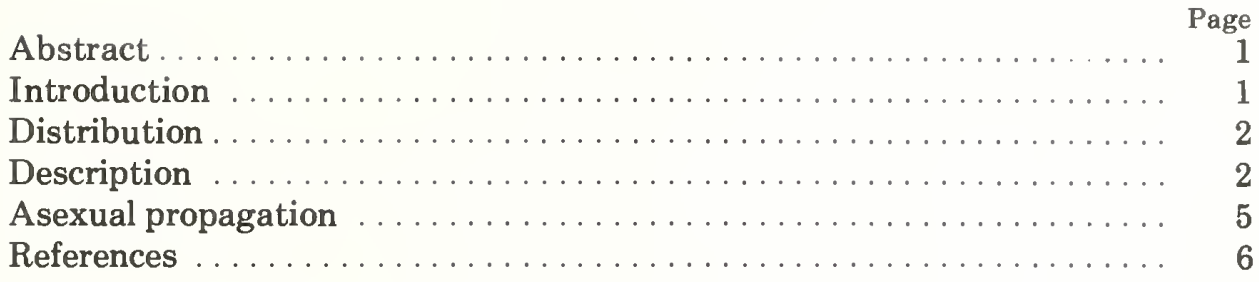

\section{ILLUSTRATIONS}

Fig.

1. Sugarcane infested with itchgrass . . . . . . . . . . . . . 1

2. Distribution of itchgrass in Louisiana, $1978 \ldots \ldots \ldots \ldots \ldots \ldots$

3. Rachis seedhead joint with sessile and pedicellate spikelets . . . . . . . . 2

4. Intact individual seedhead joints showing sessile spikelet ......... 3

5. Dissected sessile spikelet showing caryopsis, and caryopsis in various

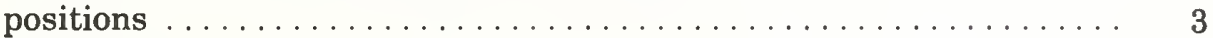

6. Mature, fertile spikelet with rachis removed $\ldots \ldots \ldots \ldots \ldots \ldots \ldots \ldots$

7. Dissected sessile spikelet $\ldots \ldots \ldots \ldots \ldots \ldots \ldots \ldots \ldots \ldots \ldots \ldots$

8. Severing itchgrass above prop roots stunts the parent plant ...... 5

9. Production of shoots and adventitious roots at nodes of itchgrass

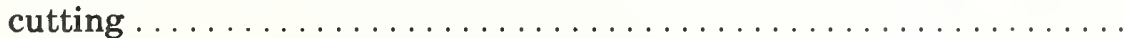





\title{
Characteristics and Distribution of Itchgrass in Louisiana
}

\author{
By James C. White, ${ }^{1}$ Donald G. Rhodes, ${ }^{1}$ and H. Lynn Walker ${ }^{2}$
}

\begin{abstract}
Itchgrass (Rottboellia exaltata $\mathrm{L}$. f.) has become established in the parishes of Lafayette, Pointe Coupee, St. Landry, St. Martin, St. Mary, St. Tammany, Lafourche, Terrebonne, Iberia, Iberville, and West Baton Rouge, and it is a serious pest in sugarcane and soybeans. The plant is described as it grows under southern Louisiana conditions. Greenhouse studies indicate that itchgrass can survive shallow cultivation but can be controlled by close mowing. Index terms: asexual propagation, itchgrass, Louisiana, soybeans, sugarcane, taxonomy (botanical), weed control.
\end{abstract}

\section{INTRODUCTION}

Itchgrass (Rottboellia exaltata L. f.) is a serious weed in soybeans, corn, cotton, peanuts, upland rice, and other crops in warm regions of the world (Holm et al. 1977). In the continental United States, it is confined to southern Louisiana and southern Florida. In Louisiana, it has caused serious problems in sugarcane (fig. 1) and soybeans. Additionally, it is one of 13 terrestrial weeds subject to the quarantine and eradication procedures authorized under the Federal Noxious Weed Act of 1974.

The weed can grow and produce seed under a wide range of environmental conditions (Millhollon 1975, Patterson and Quimby 1978). In many major agricultural areas of the United States, itchgrass has the potential to cause economic losses equal to those caused by johnsongrass (Patterson and Quimby 1978). Environmental conditions related to maximum growth

\footnotetext{
${ }^{1}$ Professor, Department of Botany and Bacteriology, Louisiana Tech University, Ruston, La. 71271.

${ }^{2}$ Research plant pathologist, Southern Weed Science Laboratory, Science and Education Administration, U.S. Department of Agriculture, P.O. Box 225, Stoneville, Miss. 38776.
}

and potential distribution have been studied by Patterson et al. (1979). Under certain conditions, as many as 4,400 joints may be produced by one mature plant (Pamplona et al. 1974).

Because the greatest potential for spread is by

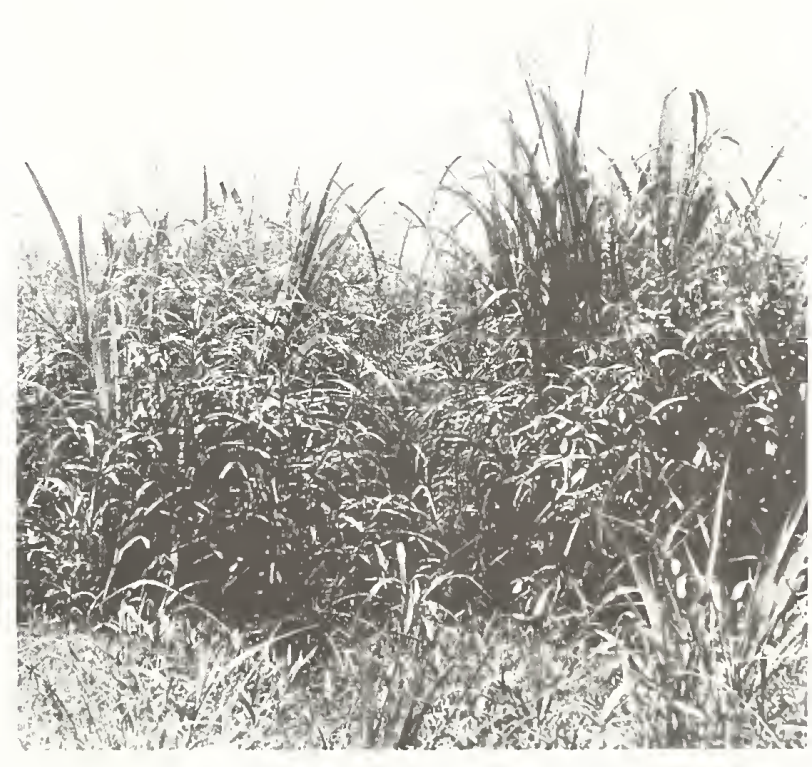

FIGURE 1.-Sugarcane infested with itchgrass. 


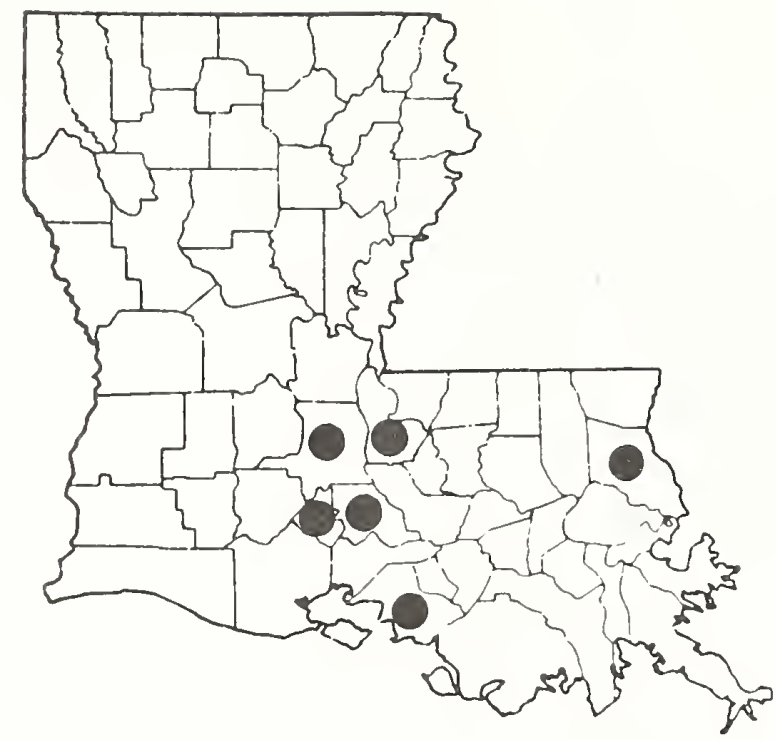

FIGURE 2.-Distribution of itchgrass in Louisiana, 1978, according to the records of Louisiana herbaria.

seed, we studied the structure of the spikelet to gain a better understanding of the weed's reproductive biology. In addition, we investigated the possibility of asexual spread by stem cuttings.

\section{DISTRIBUTION}

Since itchgrass has the capability of rapid dispersal, it is important that the distribution be documented so that the rate of spread and effectiveness of suppression procedures can be assessed. As of 1978, herbarium collections supported the occurrence of itchgrass in the following Louisiana parishes (fig. 2): Lafayette (USL, LSU), Pointe Coupee (LTU, USL), St. Landry (LTU), St. Martin (LTU, USL), St. Mary (LTU), and St. Tammany (USL). Sightings have been made in lower Lafourche and Terrebonne Parishes (Lauden 1975) and in Iberia, Iberville, and West Baton Rouge Parishes (R. W. Millhollon, personal communication), but these reports have not been vouchered in State herbaria.

\section{DESCRIPTION}

Itchgrass has been described by others (Hitchcock 1950, Holm et al. 1977), but various aspects of flower components were not included. During August and September, 1977 and 1978, rachis joints were harvested from mature plants

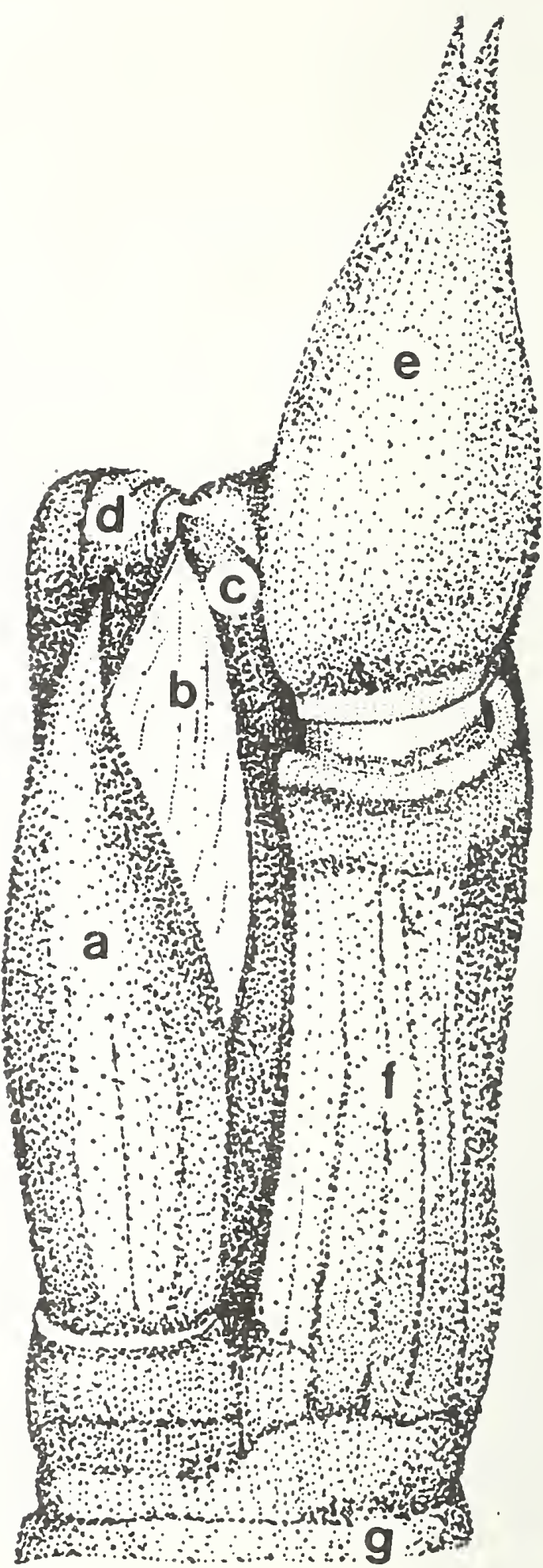

FIGURE 3.-Rachis seedhead joint with sessile and pedicellate spikelets. a, Outer glume of sessile fertile spikelet. b, Lemma. c, Inner glume of sessile spikelet. d, Concave side of rachis. e, Glume of sterile spikelet. f, Pedicel of sterile spikelet. g, Base of rachis. 


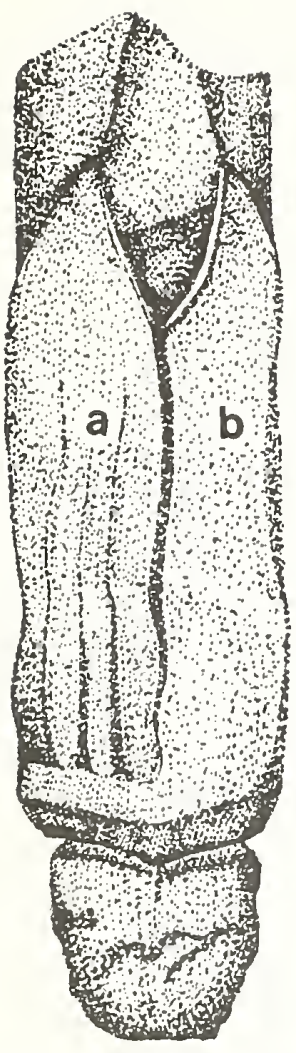

FIGURE 4.-Intact individual seedhead joints showing sessile spikelet. The pedicellate uppermost spikelet has been removed. a, Outer glume of spikelet. b, Pedicel of uppermost spikelet.

growing in sugarcane fields, St. Martin Parish, La., dissected, and studied in the laboratory.

An inflorescence is composed of numerous rachis joints in a spiciform arrangement. Each joint has several visible parts, including the rachis, a sessile spikelet, and a pedicellate spikelet (fig. 3). Immature joints are green but gradually turn a straw color; at maturity, they fall from the plant. Mature joints that have fallen to the ground are usually devoid of the sterile pedicellate spikelet and the accompanying glume (fig. 4).

The rachis joint is the fruit. The seed is a caryopsis enclosed by the palea and lemma immediately under the outer glume (fig. 5). The outer and inner glumes of the sessile spikelet, together with the caryopsis, are easily removed from the concave side of the rachis (fig. 6). The inconspicuous caryopsis often germinates in the glumes, giving the appearance that the spikelet joint is the seed. A dissected sessile spikelet with all flowering parts is shown in figure 7. Spikelet sterility was pronounced in poorly developed
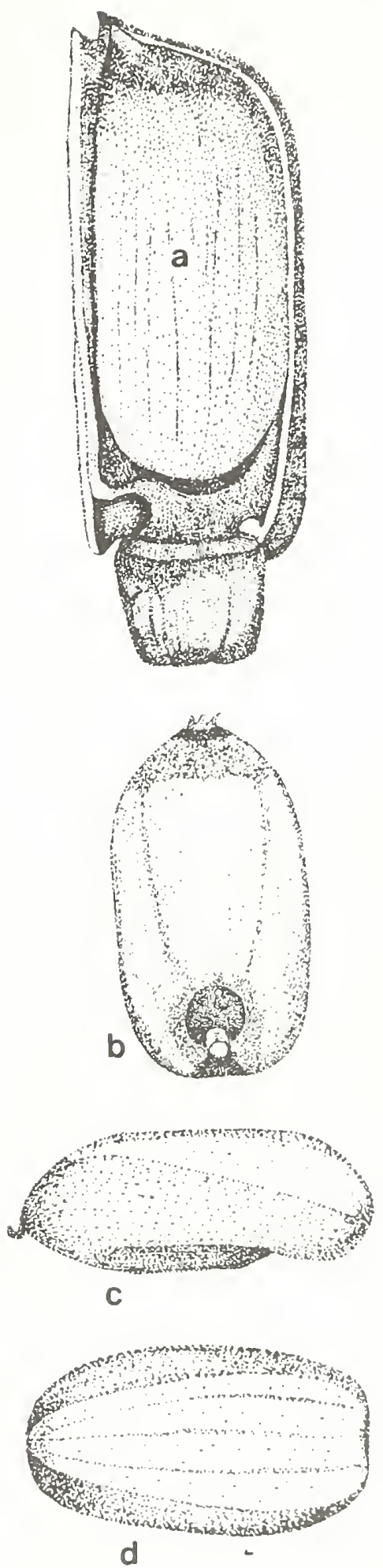

FIGURE 5.-Dissected sessile spikelet showing caryopsis, and caryopsis in various positions, a, Longitudinal view of caryopsis within glumes and rachis. b, Bottom view of caryopsis. c, Side view of caryopsis. d, Top view of caryopsis. 

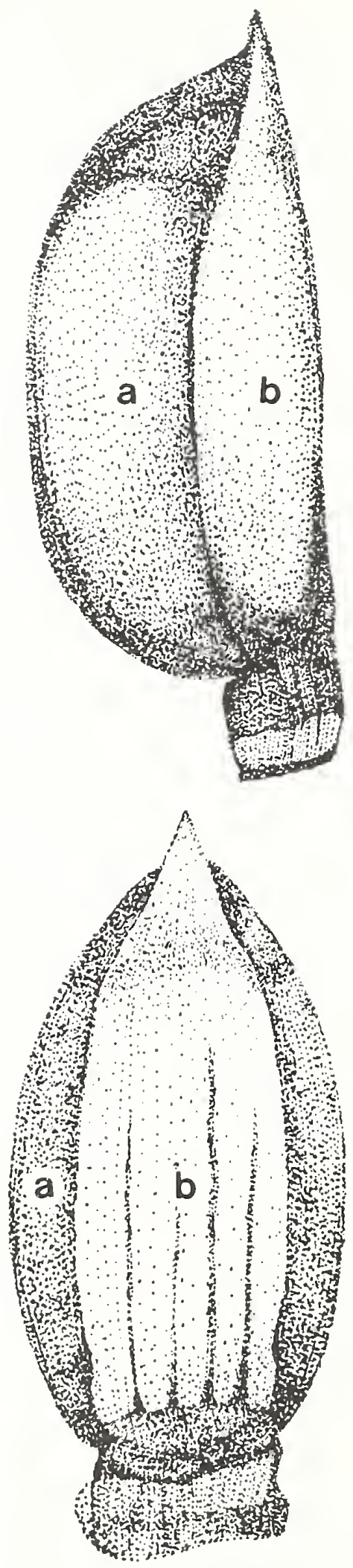

FIGURE 6. - Mature, fertile spikelet with rachis removed. a, Inner glume. $b$, Outer glume.

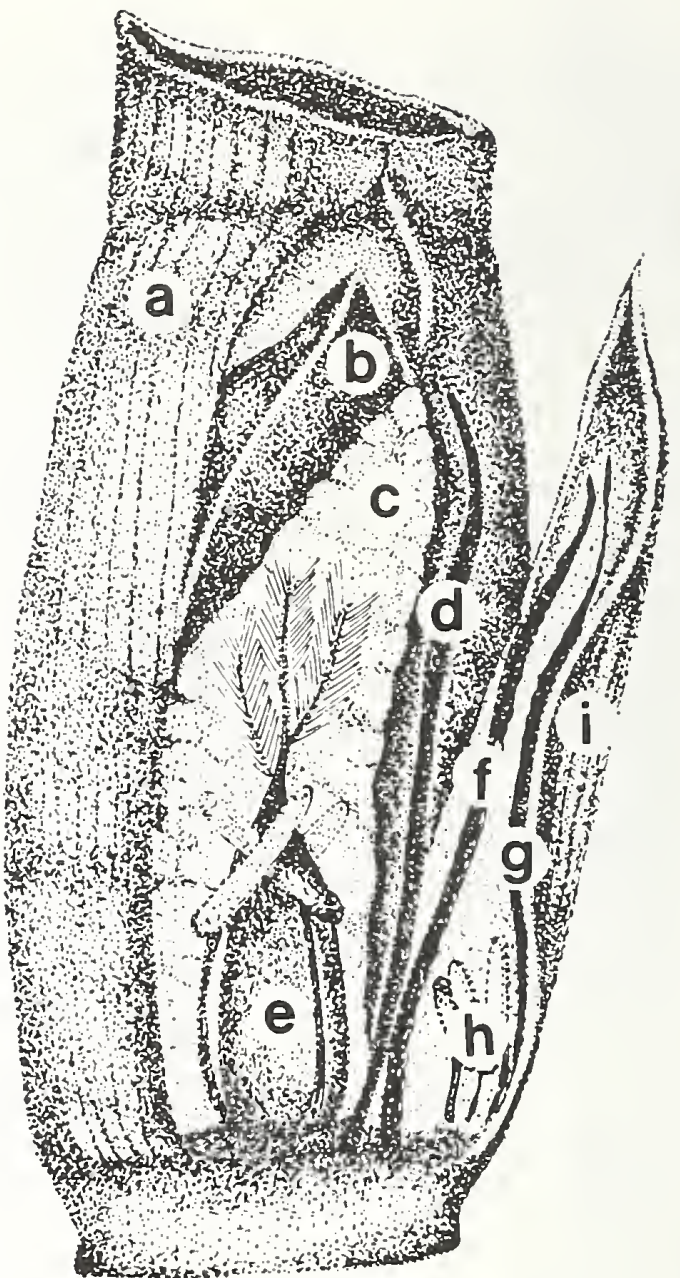

FigurE 7.-Dissected sessile spikelet. a, Rachis. b, Inner glume. c, Palea of second floret. d, Lemma of second floret. e, Pistil and three stamens. $f$, Palea of first floret. $\mathrm{g}$, Lemma of first floret. h, Rudimentary stamens. i, Outer glume.

joints near the apex of the inflorescence and in seed collected during September.

Itchgrass growing under Louisiana conditions may be formally described as follows:

Rottboellia exaltata L. f., Nov. Gram. Gen. 40. pl. 1. 1779.

Culms vigorous, $1-3 \mathrm{~m}$ tall, branched. Sheath about $2 \mathrm{~cm}$ wide, to $13 \mathrm{~cm}$ long, hispid and papillose, particularly toward the summit; lamina to $4 \mathrm{~cm}$ long, to $3 \mathrm{~cm}$ wide, finely serrulate, glabrous. Inflorescence spiciform, $9-10 \mathrm{~cm}$ long, 2-3 $\mathrm{mm}$ wide, cylindrical, the rachis articulated. Spikelets 2 per rachis joint, the uppermost pedicellate to $4 \mathrm{~mm}$, essentially sterile, glumes lanceolate, about $3 \mathrm{~mm}$ long, 1-2 $\mathrm{mm}$ wide, somewhat 


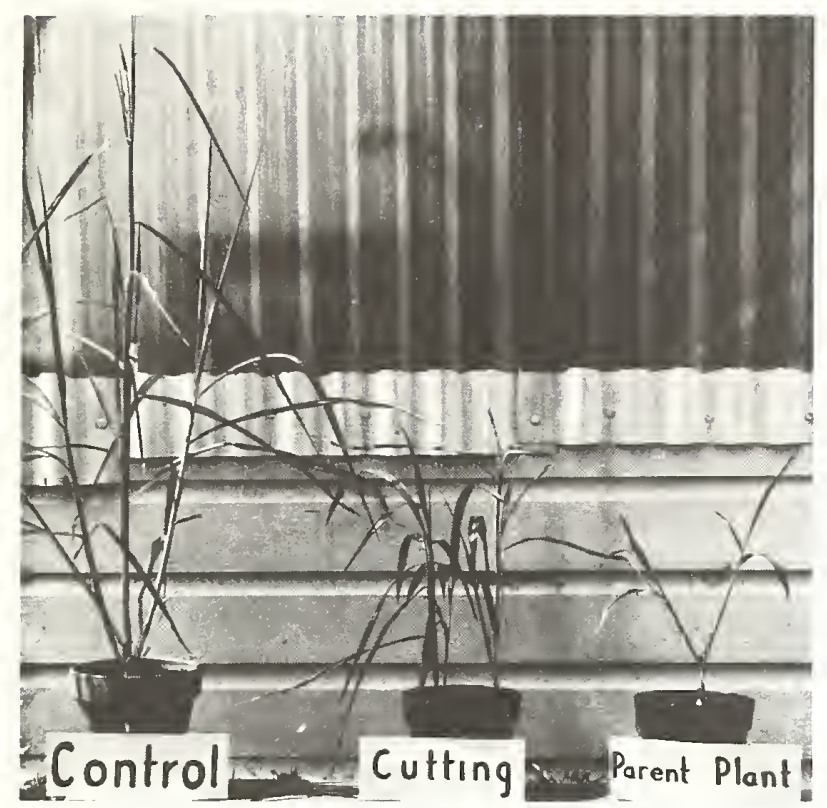

FIGURE 8.-Severing itchgrass above prop roots stunts the parent plant. Some cuttings survive and produce shoots.

indurate, sterile lemma lanceolate, $2 \mathrm{~mm}$ long, 0.5 $\mathrm{mm}$ wide, membranous and hyaline; lowermost spikelet sessile, inset within the concave rachis joint, first glume indurate, lanceolate to elliptical, 4.5-5.0 mm long, 1.5-2.0 $\mathrm{mm}$ wide, second glume somewhat indurate, ovate to suborbicular, concave, 4-5 $\mathrm{mm}$ long, 3-4 $\mathrm{mm}$ wide; first floret neuter to staminate, lemma membranous and hyaline, lanceolate to slightly obovate, $3-4 \mathrm{~mm}$ long, 1-2 $\mathrm{mm}$ wide, palea slightly indurate, lanceolate to elliptical, 4-5 mm long, 1-2 mm wide; innermost fertile floret with lemma membranous and hyaline, lanceolate, 2-3 mm long, 1-2 mm wide, palea membranous and hyaline, concave, ovate to suborbicular, 3-5 $\mathrm{mm}$ long, 2-3 $\mathrm{mm}$ wide. Caryopsis quadranguloid, $3-4 \mathrm{~mm}$ long, about 2 mm wide.

\section{ASEXUAL PROPAGATION}

In the first experiment, 80 itchgrass plants were grown in the laboratory to a height of $15 \mathrm{~cm}$ and then divided into three groups. Group 1 contained 35 plants with stems severed immediately above the base of the first leaf sheath; group 2 contained 35 plants with stems severed immediately below the base of the first leaf sheath; and group 3 consisted of 10 intact control plants. Cuttings from test plants were planted in unsterilized field soil by inserting the severed

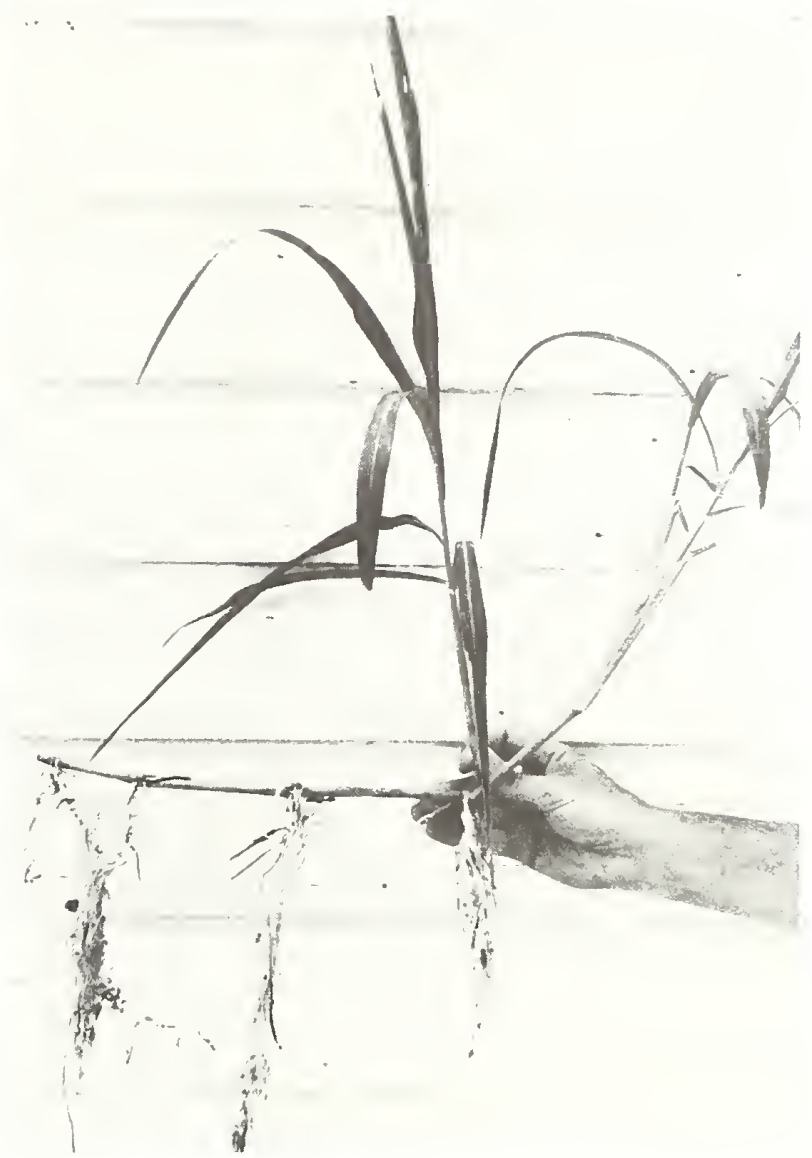

FIGURE 9.-Production of shoots and adventitious roots at nodes of itchgrass cutting. Except for exposed terminals, the stem was buried horizontally for 26 days.

basal end to an approximate depth of $2.5 \mathrm{~cm}$. The study was concluded after 40 days.

Plants in group 1 survived the treatment, and new leaves developed on several plants. However, their growth rate was slow compared to the controls'. At the conclusion of the test 20 plants $(55 \%)$ of group 1 were dead. All plants in group 2 were dead within 7 days of treatment. The surviving cuttings from both groups were severely stunted; however, at the conclusion of the experiment, 14 cuttings $(40 \%)$ had produced new leaves and adventitious roots.

A second test, carried out under greenhouse conditions, involved 50 plants 60 to $70 \mathrm{~cm}$ tall. The stems of 40 plants were severed in the internode region above the last prop root; the 10 intact plants were the controls. Seventy-five stem cuttings obtained from severed shoots were planted vertically, approximately $7.5 \mathrm{~cm}$ deep in unsterilized field soil. Additionally, 10 cuttings were planted horizontally in flats, with the ter- 
minal stem sections and leaves exposed. The plants and cuttings were observed for 26 days. Plants with severed stems had a $10 \%$ survival rate, and surviving plants were severely stunted (fig. 8). Cuttings planted vertically had a $31 \%$ survival rate, and the survivors produced extensive adventitious roots. Seven of the ten cuttings planted horizontally survived, and the stems produced extensive adventitious roots (fig. 9). Surviving cuttings produced several seeds on new growth.

These results, which agree with Millhollon's (1965), indicate that cutting itchgrass near the soil line could be a possible mechanical control. On the other hand, plants turned under during cultivation could possibly survive by producing adventitious roots.

\section{REFERENCES}

Hitchcock, A. S.

1950. Manual of the grasses of the United States.
Second ed., revised by Agnes Chase. U.S. Dep. Agric. Misc. Publ. 200, 1051 pp.

Holm, L. G.; Plucknett, D. L.; Pancho, J. V.; and Herberger, J. P.

1977. The world's worst weeds. Distribution and biology. 609 pp. University Press of Hawaii, Honolulu.

Lauden, L. L.

1975. In the field with Lloyd L. Lauden. Sugar Bull. 53: 4.

Millhollon, Rex W.

1965. Growth characteristics and control of Rottboellia exaltata L. f., a new weed in sugarcane. Sugar Bull. 44: 82-88.

1975. Weed watch. Weeds Today 6(4): 20.

Pamplona, Pablito P., and Mercado, B. L.

1974. Dormancy and germination of Rottboellia exaltata L. f. Philipp. Sci. 103(4): 191-197.

Patterson, D. T.; Meyer, C. R.; Flint, E. P.; and Quimby, P. C., Jr.

1979. Temperature responses and potential distribution of itchgrass (Rottboellia exaltata) in the United States. Weed Sci. 27: 77-82.

Patterson, D. T., and Quimby, P. C., Jr.

1978. Itchgrass - a potential noxious weed in Mississippi. Miss. Agric. For. Exp. Stn. Res. Rep. $3(18), 4$ pp. 
U. S. DEPARTMENT OF AGRICULTURE SCIENCE AND EDUCATION ADMINISTRATION P. O. BOX 53326

POSTAGE AND FEES PAID

U. S. DEPARTMENT OF

NEW ORLEANS, LOUISIANA 70153

OFFICIAL BUSINESS

PENALTY FOR PRIVATE USE, \$300

AGR 101 